\title{
PENGKONDISIAN NILAI KARAKTER NASIONALISME DALAM PEMBELAJARAN TEMATIK DI SEKOLAH DASAR
}

\author{
Bistari Basuni \\ Dosen Pendidikan Matematika FKIP Universitas Tanjungpura Pontianak \\ Email: bistari@fkip.untan.ac.id
}

\begin{abstract}
Abstrak
Nilai-nilai karakter pada pada sebagian besar siswa sesungguhnya ada dan sudah dimiliki, namun nilai karakter tersebut bisa saja terpendam dan terkikis oleh pengalaman kontkestual. Karenanya, selaku guru nilai-nilai karakter tersebut perlu dimunculkan (ditumbuhkan) dengan usaha dan upaya yang konsisten dan terbaca oleh peserta didik. Upaya lain yang dapat dilakukan pendidik, yaitu mengkondisikan nilai-nilai karakter dalam pembelajaran. Mengkondisikan nilai-nilai karakter dalam pembelajaran merupakan usaha sadar dan disengaja. Perlakuan seperti ini merupakan suatu ciri dalam pembelajaran yang perlu dimaksimalkan, agar memperoleh hasil yang berimbang. Mengkondisikan nilai-nilai karakter dalam pembelajaran dapat dilakukan dengan cara mengembangkan tujuan pembelajaran dalam karakteristik nilai-nilai karakter yang diharapkan. Berdasarkan paparan hasil dan pembahasan permasalahan tersebut dapat disimpulkan sebagai berikut: (1) pengkondisian karakter nasionalis oleh guru tergolong sedang atau biasa-biasa saja, perlu pembiasaan pada siswa agar pengkondisian karakter nasionalis dapat berjalan baik atau sangat baik; (2) tidak semua butir indikator karakter nasionalis untuk dapat direalisasikan.
\end{abstract}

\section{Kata Kunci: Mengkondisikan, Nilai-Nilai Karakter, dan Pembelajaran}

\section{PENDAHULUAN}

Sistem Pendidikan Nasional Pasal 3 berdasarkan Undang-Undang No. 20 Tahun 2003 menyebutkan bahwa Pendidikan Nasional berfungsi mengembangkan kemampuan dan membentuk karakter serta peradaban bangsa yang bermartabat dalam rangka mencerdaskan kehidupan bangsa. Pendidikan Nasional bertujuan untuk mengembangkan potensi peserta didik agar menjadi manusia yang beriman dan bertakwa kepada Tuhan Yang Maha Esa, berakhlak mulia, sehat, berilmu, cakap, kreatif, mandiri, dan menjadi warga negara yang demokratis dan bertanggung jawab. Hal tersebut berkaitan dengan pembentukan karakter peserta didik melalui pendidikan.

Program PPK (Penguatan Pendidikan Karakter) digagas oleh Kemdikbud sejalan dengan upaya menyukseskan Gerakan Nasional Revolusi Mental (GNRM) yang digagas Presiden Joko Widodo. Dalam hal ini, lembaga yang menjadi prioritas adalah pendidikan dasar, mulai dari jenjang PAUD, SD, lalu SMP. Saat ini, program PPK mulai disambut oleh guru-guru dan kepala sekolah. Terbukti dengan diterapkannya program-program khusus di internal sekolah baik dalam bentuk pembiasaan, kegiatan ekstrakurikuler, maupun kokurikuler.

Meski dalam pelaksanaannya ada yang sudah maksimal dan ada juga yang belum, namun setidaknya kita melihat seluruh pihak mulai menyadari begitu pentingnya pendidikan karakter dibudayakan untuk anak-anak di tengah kemerosotan akhlak yang dikeluhkan banyak pihak. Saat ini Kemdikbud telah merilis 5 nilai (karakter) utama yang harus diprioritaskan dalam melaksanakan Pengembangan Pendidikan Karakter di sekolah. Ini menjadi jawaban bagi sebagian guru yang bingung, mau mandahulukan karakter yang mana untuk dibiasakan pada siswa. Sedangkan karakter sendiri jumlahnya banyak (setidaknya ada 18 karakter yang dirilis Kemdikbud beberapa tahun lalu).

Terkait dengan hal tersebut, sangat menarik bila guru dalam pembelajaran sehari-hari dengan sengaja mengkondisikan ketercapaian pembelajaran yang dilakasanakan juga mengkondisikan ketercapian karakter yang sesuai. Ini berarti, guru berupaya mencapai tujuan pembelajaran, juga guru dalam waktu yang bersamaan dengan sengaja dan sadar untuk juga mengkondisikan pembelajaran dengan memantau ketercapaian karakter yang diingingkan. Jauh diharapkan untuk dapat menjadi kepribadian mereka dalam bergaul di masyarakat, mengembangkan kehidupan masyarakat yang lebih sejahtera, serta mengembangkan kehidupan bangsa yang bermartabat. Elihami\& Firawati (2017).

Pembelajaran yang dilakukan guru di kelas merupakan usaha sadar dan sengaja, karena itu guru juga bisa berupaya untuk dengan sengaja dan sadar untuk mengkondisikan untuk mengembangkan nilainilai karakter yang sesuai. Mungkin dapat dilakukan dalam pembelajaran dimaksud tidak perlu banyak karakter yang dituntut. Dengan menuntut dan mengkondisikan satu nilai karakter yang konsisten dan terukur, itu sudah memadai. Apalagi pengkondisian dimaksud masuk dalam pembelajaran. Hal ini, membuat siswa untuk mengikuti secara seksama karena bukan kegiatan sampingan, tapi kegiatan yang harus dialami. Pendidikan karakter seharusnya membawa peserta didik ke pengenalan nilai secara kognitif, penghayatan nilai secara afektif, dan akhirnya ke pengamalan nilai secara nyata. Inilah rancangan pendidikan karakter (moral) yang oleh Thomas Lickona disebut moral knowing, moral feeling, dan moral action. (Lickona, 1991)

Secara garis besar tentang pengertian lima karakter utama, Pusat Penilaian Pendidikan, Badan Penelitian dan Pengembangan, Kemndikbud (2019: 6) memaparkan sebagai berikut: 1) Religius, mencerminkan keberimanan kepada Tuhan Yang Maha Esa. 2) Nasionalis, menempatkan kepentingan bangsa dan negara di atas kepentingan diri dan kelompoknya. 3) Mandiri, tidak bergantung kepada orang lain dan mempergunakan tenaga, pikiran, waktu untuk merealisasikan harapan, mimpi, dan cita-cita. 4) Gotong royong, mencerminkan tindakan menghargai semangat kerja sama dan bahu membahu 
menyelesaikan persoalan bersama. 5) Integritas, upaya menjadikan dirinya sebagai orang yang selalu dapat dipercaya dalam perkataan, tindakan, dan pekerjaan. Lima nilai karakter utama dalam indikator dan implementasinya dirincikan sebagai berikut. (1) Nilai karakter religius mencerminkan keberimanan terhadap Tuhan yang Maha Esa yang diwujudkan dalam perilaku melaksanakan ajaran agama dan kepercayaan yang dianut, menghargai perbedaan agama, menjunjung tinggi sikap toleran terhadap pelaksanaan ibadah agama dan kepercayaan lain, hidup rukun dan damai dengan pemeluk agama lain. Implementasi nilai karakter religius ini ditunjukkan dalam sikap cinta damai, toleransi, menghargai perbedaan agama dan kepercayaan, teguh pendirian, percaya diri, kerja sama antar pemeluk agama dan kepercayaan, anti perundungan dan kekerasan, persahabatan, ketulusan, tidak memaksakan kehendak, mencintai lingkungan, melindungi yang kecil dan tersisih; (2). Nilai karakter nasionalis merupakan cara berpikir, bersikap, dan berbuat yang menunjukkan kesetiaan, kepedulian, dan penghargaan yang tinggi terhadap bahasa, lingkungan fisik, sosial, budaya, ekonomi, dan politik bangsa, menempatkan kepentingan bangsa dan negara di atas kepentingan diri dan kelompoknya. Sikap nasionalis ditunjukkan melalui sikap apresiasi budaya bangsa sendiri, menjaga kekayaan budaya bangsa, rela berkorban, unggul, dan berprestasi, cinta tanah air, menjaga lingkungan, taat hukum, disiplin, menghormati keragaman budaya, suku, dan agama; (3). Nilai karakter mandiri merupakan sikap dan perilaku tidak bergantung pada orang lain dan mempergunakan segala tenaga, pikiran, waktu untuk merealisasikan harapan, mimpi dan cita-cita. Siswa yang mandiri memiliki etos kerja yang baik, tangguh, berdaya juang, profesional, kreatif, keberanian, dan menjadi pembelajar sepanjang hayat; (4). Nilai karakter gotong royong mencerminkan tindakan menghargai semangat kerja sama dan bahu membahu menyelesaikan persoalan bersama, menjalin komunikasi dan persahabatan, memberi bantuan/pertolongan pada orang-orang yang membutuhkan. Diharapkan siswa dapat menunjukkan sikap menghargai sesama, dapat bekerja sama, inklusif, mampu berkomitmen atas keputusan bersama, musyawarah mufakat, tolong menolong, memiliki empati dan rasa solidaritas, anti diskriminasi, anti kekerasan, dan sikap kerelawanan; (5) Nilai karakter integritas merupakan nilai yang mendasari perilaku yang didasarkan pada upaya menjadikan dirinya sebagai orang yang selalu dapat dipercaya dalam perkataan, tindakan, dan pekerjaan, memiliki komitmen dan kesetiaan pada nilai-nilai kemanusiaan dan moral. Karakter integritas meliputi sikap tanggung jawab sebagai warga negara, aktif terlibat dalam kehidupan sosial, melalui konsistensi tindakan dan perkataan yang berdasarkan kebenaran. Seseorang yang berintegritas juga menghargai martabat individu (terutama penyandang disabilitas), serta mampu menunjukkan keteladanan.

Religius dalam pembelajaran dapat dikondisikan pada hal-hal yang sifat lebih umum. Untuk beriman dan bertaqwa, memulai pembelajaran dengan keyakinan masing-masing. Menanamkan sikap percaya pada kemampuan sendiri atas ridho ilahi. Mengaitkan konsep pembelajaran yang selaras dengan perintah-Nya. Misalnya, dalam pembelajaran IPA konsep pertumbuhan bahwa untuk menjaga kelestarian, ada efek secara langsung atau tak langsung bila kelestarian tersebut diabaikan. Kepedulian terhadap lingkungan yang selalu dijaga akan membawa pada keharmonisan dalam system. Akan berbeda halnya jika lingkungan tersebut diabaikan. Saling tolong menolong untuk kebaikan adalah perbuatan terpuji, namun harus dipertegas yang dimaksud tolong menolong adalah yang mengarah pada kebaikan. Kondisi tolong menolong tersebut bisa salah persepsi bagi siswa tertentu, sebab jika salah makna efeknya tidak terasa langsung. Maka ada baiknya, makna tolong menolong tersebut diarahkan untuk kebaikan. Jika diperlukan ungkapkan bahwa tolong menolong yang salah persepsi dapat berakibat "tolong menolong" terbungkus oleh kebaikan, namun didalamnya sesungguhnya melanggar aturan-aturan yang ditetapkan.

Integritas artinya selalu berupaya menjadikan dirinya sebagai orang yang bisa dipercaya dalam perkataan, tindakan, dan pekerjaan. Siswa yang berintegritas akan berhati-hati dalam menjalin pergaulan, sebab kepercayaan yang diberikan temantemannya itu mahal harganya. Dengan maraknya praktik bullying dan perundungan, sekolah perlu membuat kebijakan tegas bahwa siswa di sekolah harus berkata dan bertindak positif antar teman sebagai bagian dari pembiasaan melatih karakter integritas. Berikut paparan indikator integritas, yaitu: (1) bisa dipercaya dalam perkataan, tindakan dan integritas; (2) komitmen dipegang teguh; (3) selalu menepati janji; (4) taat asas; (5) jujur; dan (6) transparan.

Nasionalisme dapat diartikan bahwa menempatkan kepentingan bangsa dan Negara di atas kepentingan pribadi dan kelompok. Cinta tanah air merupakan salah satu indikator karakter nasionalis yang dapat melekat pada diri siswa. Kita dapat mengaitkan setiap pembelajaran dengan karakter nasionalis, yakni dengan cara membawa kasus sesuai mata pelajaran. Konsep-konsep yang ada dalam pembelajaran sememangnya tidak semua mudah dibuat dalam bentuk kasus sehingga yang merespon kasus tersebut tidak semua siswa. Itu menggambarkan siswa mempunyai rekam pengalaman yang sama. Demikian juga semangat kebangsaan, setiap siswa cenderung akan memiliki persepsi yang tidak sama. Kondisi ini dilatarbelakangi oleh pembentukan rasa kebangsaan dalam jiwa mereka yang lebih dekat oleh pembentukan sikap nasionalisme oleh orang terdekat. Mengembangkan indikator demokratis dapat dilakukan lebih tepat pada beberapa metode pembelajaran yang mengarahkan siswa pada bentuk yang lebih mengahargai teman dalam berpendapat. Metode pembelajaran yang lebih mengandalkan pada adu pendapat akan dapat mewarnai indikator demokratis dalam pembelajaran tersebut. Untuk indikator rela berkorban dalam pembelajaran dapat ditunjukkan dengan unggul dan berprestasi. Namun demikian tidak semua siswa dapat digolongkan unggul dan berprestasi, maka dapat mengkondisikan dalam hal yang lain, seperti menjaga lingkungan dan taat hukum. Artinya nilai karakter nasionalis, bila tidak dapat diupayakan dalam hal tertentu maka kita dapat focus pada penciri kegiatan yang lain. Dapat disimpulkan indikator dari karakter nasionalisme, yaitu: (1) bangga sebagai bangsa Indonesia; (2) cinta tanah air dan bangsa; (3) rela berkorban demi bangsa; (4) menerima kemajukan; (5) bangga pada budaya 
beraneka ragam; (6) mengahargai jasa para pahlawan; dan (6) mengutaman kepentingan Negara dari pada kepentingan indivudu atau kelompok.

Mandiri yang dapat diartikan tidak memiliki ketergantungan dengan orang lain adalah terkait dengan sikap dan perilaku. Tentunya perilaku sebaiknya tegas dan memiliki cermin diri sendiri. Ketergantungan disini lebih dimaksudkan sebagai penyesuaian agar orang lain juga dapat mandiri. Untuk mewujudkan sikap mandiri tersebut dan mempergunakan segala tenaga, pikiran, waktu untuk merealisasikan harapan, mimpi dan cita-cita. Siswa yang mandiri memiliki etos kerja yang baik, tangguh, berdaya juang, profesional, kreatif, keberanian, dan menjadi pembelajar sepanjang hayat. Indikator dari karakter mandiri yaitu (1) ketidaktergantungan terhadap orang lain; (2) memiliki keteguhan dan kepercayaan diri; (3) bersikap disiplin; (4) bertanggungjawab; (5) memiliki inisiatif sendiri; dan (6) baik dalam kontrol diri. Ada aspek yang berbeda bila dikaji dengan kemandirian belajar. Karakter mandiri sifatnya lebih umum dari kemandirian belajar. Apa yang ada pada indikator mandiri dikombinasikan dan dicocokkan pada indikator sifatnya pembelajaran. Sehingga kemandirian belajar lebih menekankan pada pengkondisian indikator mandiri dalam pembelajaran. Dapat dirincikan bahwa kemandirian belajar yaitu: (1) memiliki kesiapan baik dalam menghadapi pembelajaran; (2) belajar tak tergantung dengan orang lain; (3) teguh dan percaya diri dalam belajar; (4) memiliki insiatif belajar; dan (5) bertanggungjawab dalam proses pembelajaran.

Nilai karakter berikutnya adalah nilai karakter gotong royong yakni mencerminkan tindakan mengahargai kerja sama dan bahu membahu menyelesaikan persoalan bersama. Sudah jelas, tradisi gotong royong semakin lama semakin hilang akibat arus teknologi yang membuat siapapun bisa menyelesaikan pekerjaan sendiri. Hal ini harus diputus, salah satunya lewat pembiasaanpembiasaan di sekolah seperti kerja bakti, mengedepankan musyawarah dan saling menghargai antar teman. Indikator nilai karakter gotong royong yang dapat dirincikan yaitu: (1) tolongmenolong, (2) memiliki sifat solidaritas, (3) komitmen atas keputusan bersama, (4) anti diskriminasi, dan (5) sikap kerelawanan. Nilai karakter gotong royong dalam pembelajaran dapat direalisasikan dalam beberapa tindakan seperti, melakukan diskusi kelompok, memberikan bantuan pembelajaran pada teman, melaksanakan aturan yang sudah menjadi keputusan kelas/sekolah, tidak membedakan antar teman, dan siap membantu dalam arah positif bila diperlukan. Tentunya yang dimaksud dalam indikator tersebut sifatnya pada arah yang konstruktif dan positif.

\section{METODE PEMECAHAN MASALAH}

Dalam tulisan ini, pengkondisian nilai karakter yang dimaksudkan hanya salah satu dari lima nilai karakter yang dimaksud, yaitu karakter nasionalis. Ada beberapa hal yang perlu dicermati dalam melakukan pengkondisian nilai karakter nasionalis dalam pembelajaran. Untuk pengkondisian nilai karakter nasionalis dalam pembelajaran dipilih di sekolah dasar dalam pembelajaran matematika.

Untuk pemecahan masalah terkait dengan pengkondisian nilai karakter nasionalis dalam pembelajaran matematika di sekolah dasar dilakukan beberapan kegiatan berikut: (1) Tanya jawab perwakilan guru di lapangan atau lokasi penulisan. Cukup diambil perwakilan yang dianggap guru komunikatif sehingga diharapkan banyak informasi yang relevan dapat diperoleh. (2) Analisis RPP guru dikaitkan dengan indikator karakter nasionalis. RPP yang ada, dianalisis bersama guru dimaksud. Harapannya guru dapat memberikan alasan yang diminta dan jika memungkinkan dapat memberikan masukan untuk hal-hal tertentu. Disamping itu juga dapat dijadikan pembekalan bagi guru tersebut untuk penyusunan RPP berikutnya; (3) Observasi beberapa guru dalam pembelajaran di kelas yang focus dalam mengembangkan nilai karakter nasionalis. Observasi pelaksanaan pembelajaran dilakukan pada beberapa guru, dengan harapan dapat meperoleh langsung tentang pelaksanaan pembelajaran apakah mengaitkan dengan sengaja indikator karakter nasionalis; (4) Merancang RPP pembelajaran matematika sekolah dasar yang memuat indikator karakter nasionalis. Bersama guru untuk merancang RPP yang memuat indikator karakter nasionalis; (5) Memvalidasikan RPP matematika sekolah dasar berkarakter nasionalis pada teman sejawat atau kepala sekolah. Sebelum pelaksanaan dalam pembelajaran di kelas, RPP perlu diajukan untuk divalidasi oleh validator, yakni teman sejawat atau kepala sekolah; (6) Merevisi RPP hasil validasi. Masukan dari hasil validasi tersebut dijadikan salah satu acuan untuk membenahi dan merevisi RPP; (7) Melaksanakan pembelajaran sesuai RPP hasil validasi yang diobservasi. Berdasarkan lembar observasi yang sudah dibuat dengan memperhatikan indikator karakter nasionalis, maka pengamatan pelaksanaan pembelajaran di kelas pada guru diamati memalui lembar observasi tersebut. (8) Refleksi dengan merujuk hasil observasi. Selanjutnya, hasil observasi tersebut dapat dijadikan salah satu bahan pertimbangan dalam kegiatan refleksi, sehingga diharapkan dapat ditemukan kelebihan dan utamanya kelemahan dari temuan yang ada; (9) Merancang RPP berikutnya dengan mempertimbangkan hasil refleksi. Untuk merancang RPP berikutnya tentu pertimbangan utama adalah hasil refleksi, dan pertimbangan yang lain adalah masukan-masukan yang konstruktif dari observer. Semua tersebut bermuara pada indikator karakter nasionalis.

Metode pemecahan masalah yang dirancang di atas merupakan upaya untuk membuat sebuah pembelajaran dapat dikondisikan dengan memuat karakter nasionalis. Tentu dalam pelaksanaan pembelajaran dapat dipengaruhi faktor intern dan ekstern. Faktor intern yakni kepiawaian seorang guru dalam memenej pelaksanaan pembelajaran dalam kelas agar lebih efektif. Sedangkan faktor ekstern satu diantaranya adalah kondisi siswa yang belum tentu stabil setiap saat, dan banyaknya siswa yang bisa stabil dalam pelaksananan pembelajaran.

\section{HASIL DAN PEMBAHASAN \\ PERMASALAHAN}

Pelaksanaan dilapangan dengan cara melakukan wawancara pada tiga guru sekolah dasar yang mengajar materi matematika, yakni WP, ST, dan YN (dua guru SD swasta dan satu guru SD Negeri) terungkap bahwa mereka tidak dengan sengaja untuk focus pada nilai-nilai karakter nasionalis. Hasil wawancara tersebut terungkap bahwa guru melaksanakan pembelajar lebih focus pada pencapaian tujuan pembelajaran, yang sifatnya 
kognitif. Penyentuhan nilai karakter nasionalis lebih pada nasehat dan wejangan yang tak dikaitkan dengan kesesuaian indikator karakter naionalis tersebut.

Selanjutnya meminta kesediaan guru untuk memperlihatkan RPP pembelajaran matematika dan mengajak diskusi tentang RPP tersebut. Hasil diskusi dengan guru-guru tersebut terungkap bahwa RPP yang dibuat ada mencantumkan karakter, namun sifatnya hanya dampak pengiring dan nilai karakter yang diungkapkan hanya disampaikan melalui nasehat namun tidak ditindaklanjuti dalam perkembangannnya pada siswa.

Hasil monitoring dan observasi penulis pada tiga guru tersebut dalam kelas daring yang dilaksanakan melalui google.meet terungkap bahwa pelaksanaan pembelajaran kelas daring cukup sulit untuk menerapkan pembelajaran yang mengkondisikan nilai karakter nasionalis. Namun demikian, pelaksanaan kegiatan pembelajaran ini difokuskan dalam pembelajaran tatap muka. Dengan harapan, kondisi yang dimaksud agar lebih kontekstual. Ada beberapa alasan yang diungkapkan guru, bahwa pengkondisian yang dimaksud belum begitu dipahami para guru karena yang dilakukan dalam pembelajaran oleh beberapa guru tersebut cenderung pada pembiasaan-pembiasaan yang dianggap kondusif oleh guru. Namun dari para guru tersebut belum melakukan kegiatan yang mengarah pada pengembangan karakter yang terukur.

Tahapan berikutnya adalah melakukan diskusi bersama para guru untuk merancang pembelajaran dalam bentuk RPP yang mengarah pada pembelajaran dengan mengkondisikan nilai karakter nasionalis dalam pembelajaran berikutnya. Beberapa tahapan yang dilakukan yakni (1) kesepahaman tentang pengkondisian karakter dalam pembelajaran, (2) indikator karakter nasionalis secara umum; (3) indikator karakter nasionalis dalam pembelajaran; (4) membuat RPP yang memuat indikator karakter nasionalis dalam pembelajaran; dan (5) membuat lembar observasi pelaksanaan pembelajaran yang mengkondisikan karakter nasionalis.

Untuk melakukan kesepahaman dalam usaha pengkondisian karakter dalam pembelajaran, maka dilakukan menyamakan persepsi tentang butir-butir indikator karakter nasionalis. Diantara indikator dari karakter nasionalisme yang tergolong a lot dalam diskusi adalah mengutaman kepentingan Negara dari pada kepentingan indivudu atau kelompok. Sebab butir ini tergolong sukar untuk direalisasikan dalam pelaksanaan pembelajaran pada materi peredaran darah manusia. Selanjutnya mengupas bersama tentang enam indikator secara umum tersebut, yang diupayakan dapat direalisasikan dalam pembelajaran di kelas melalui rancangan sebuah RPP. Disepakati bahwa indikator dimaksud dapat diupayakan untuk dimasukkan dalam proses belajar mengajar, yakni pada kegiatan awal, kegiatan inti dan kegiatan akhir. Selanjutnya agar kegiatan dalam proses pembelajaran di kelas dapat terukur untuk pelaksanaan indikator karakter nasionalis, maka disepakati pembuatan lembar observasi.

Berikut disajikan hasil diskusi pembuatan RPP dan lembar observasi. Untuk RPP yang disajikan adalah bagian kegiatan proses belajar mengajarnya, yaitu kegiatan pendahuluan, kegiatan inti dan kegiatan akhir. Untuk kelengkapan dari seluruh RPP dapat disesuaikan lebih lanjut. Intinya adalah bahwa komponen lain dari RPP memungkinkan untuk dimuat indikator karakter nasionalis.

\section{Rencana Pelaksanaan Pembelajaran (Bagian dari Keseluruhan RPP-Daring ditampilkan yang dianggap relevan). \\ Tujuan Pembelajaran.}

(1) Melalui pengamatan contoh-contoh syair yang disajikan guru pada powerpoint, siswa dapat merincikan ciri-ciri syair dengan tepat. (HOTS: C5); (2) Dengan mengamati dan mendengarkan pembacaan pantun dan syair dari tayangan youtube yang ditampilkan, siswa dapat menciptkan sebuah pantun dengan percaya diri. (HOTS: P4); (3) Melalui diskusi kelompok dan eksplorasi di internet serta buku paket, siswa dapat menyimpulkan penyebab dari gangguan organ peredaran darah (demam berdarah ) dengan tepat. (HOTS: C5); (4) Melalui diskusi kelompok dan eksplorasi di internet serta buku paket, siswa dapat mendesain langkah-langkah usaha pencegahan terhadap gangguan organ peredaran darah (demam berdarah) dengan tepat. (HOTS: P5)

\section{Materi Pembelajaran.}

(1) Perbedaan Pantun dan Syair, (2) Jenis-jenis gangguan organ peredaran darah

\section{Langkah-langkah Pembelajaran}

\begin{tabular}{ll}
\hline \multicolumn{1}{c}{ Kegiatan } & \\
\hline $\begin{array}{l}\text { Kegiatan } \\
\text { penda- }\end{array}$ & 1. Guru mengirim pesan melalui WA group tentang jadwal kegiatan \\
huluan & hari ini. \\
& 2. Siswa melaksanakan Shalat Dhuha dan Tadarus secara mandiri . \\
& 3. Siswa mengisi absen melalui link Google form yang dikirimkan \\
& melalui chat WA group. \\
& 4. Guru mengirimkan link zoom meet melalui group WA \\
& 5. Setelah bergabung di Zoom meet, guru melakukan pembukaan \\
& dengan salam dan dilanjutkan dengan membaca Doa \\
& 6. Melakukan presensi dan menanyakan keadaan siswa. \\
& 7. Melakukan apersepsi dengan mengaitkan materi sebelumnya dengan Materi yang akan \\
& dipelajari. Juga sertakan beberapa indikator karakter nasionalisme. \\
a. Bagian organ tubuh mana yang berfungsi sebagai alat pemompa darah ? .... (alat dengan
\end{tabular}
fungsinya, dan masing-masing alat tersebut saling menunjang/membantu, harmonis dengan keberagaman, yang satu tidak dapat merasa lebih dari yang lain)

b. Apakah melalui pantun kita bisa menyampaikan sebuah nasehat untuk selalu menjaga kesehatan jantung kita? ...( pantun dikondisikan dengan tema indikator karakter naisonalis, yaitu cinta tanah air, dan menghargai jasa pahlawan,)

c. Guru mempersilakan salah satu siswa untuk membacakan sebuah pantun di slide ppt. 
8. Guru memberi gambaran tentang tujuan pembelajaran hari ini dengan mengaitkan pengalaman siswa; serta menggali pantun bertema bangga menjadi bangsa Indonesia.

9. Guru memberikan gambaran tentang manfaat pembelajaran hari ini yang berkaitan dengan kehidupan sehari-hari siswa; serta mengaitkan bangga menjadi bangsa Indonesia.

Kegiatan 1. Guru menyajikan tampilan media powerpoint beberapa contoh pantun dan syair. inti Diupayakan contoh pantun dengan tema rela berkorban.

2. Siswa mengamati dan mencari informasi dari media powerpoint tentang ciri-ciri pantun dan syair.

3. Guru melakukan tanya jawab mengenai hasil dari pengamatan siswa terhadap beberapa contoh pantun dan syair yang di sajikan dalam media powerpoint.

4. Siswa merespon pertanyaan dari guru dengan merincikan ciri-ciri pantun dan ciri-ciri syair.

5. Siswa dapat berdiskusi tentang pantun yang memuat rela berkorban, serta syair tema cinta tanah air.

6. Guru memberikan pujian/motivasi kepada siswa yang bisa menjawab/merespon pertanyaan dari guru.

7. Guru menampilkan sebuah video contoh pembacaan pantun dan syair, kemudian siswa menciptakan sebuah pantun dan nanti pantun tersebut di tulis di lembar LKPD secara mandiri yang linknya akan dikirimkan melalui chat group WA. Siswa didorong untuk mencipatakan pantun sesuai tema karakter nasionalis, seperti cinta tanah air, bangga sebagai bangsa Indonesia.

8. Link LKPD nya akan dikirimkan melalui chat group WA.

9. Guru menayangkan sebuah video youtube di media powerpoint tentang gangguan organ peredaran darah.

10. Siswa mengamati video dan menemukan informasi tentang jenis-jenis gangguan organ peredaran darah. Selanjutnya menganalogikan ragam alat peredaran darah dan ragam budaya/etnis

11. Kemudian siswa menyusun jenis-jenis gangguan organ peredaran darah menurut faktor keturunan dan non keturunan.

12. Guru mengelompokkan siswa menjadi 5 kelompok belajar.

13. Setiap kelompok melakukan diskusi menggunakan Zoom meet atau Google meet yang siswa akses secara mandiri. Guru mengarahkan siswa mengupas ragam alat peredaran darah sebagai suatu kebesaran Tuhan, dan kebanggaan yang sama pada budaya beraneka ragam

14. Siswa berdiskusi untuk mencari 2 penyebab dari gangguan organ peredaran darah dan 2 langkah usaha pencegahan terhadap gangguan organ peredaran darah (demam berdarah.

15. Siswa diberi kesempatan selama 20 menit untuk berdiskusi.

16. Masing-masing perwakilan kelompok mengisi hasil diskusinya di Google form yang linknya akan dikirimkan melalui chat digroup WA.

17. Guru memulai zoom meeting kembali dengan menampilkan hasil diskusi pada google form dari masing-masing kelompok.

18. Setiap kelompok menanggapi jawaban dari kelompok lain.

19. Guru memberikan penguatan tentang hasil resume kelompok dengan menampilkan PPT dan video penyebab dan cara mencegah gangguan organ peredaran darah.

20. Guru melakukan umpan balik dengan bertanya jawab.

21. Guru coba mengaitkan antara indikator karakter nasionalis yang sesuai dengan materi peredaran darah manusia. Bahwa (1) alat dalam peredaran beragam, dan (2) berjalan harmonis karena saling mendukung antara alat-alat tersebut. Hal tersebut mirip dengan keragaman bangsa Indonesia, dan yang satu sebaiknya dapat mendukung yang lain.

Kegiatan 1. Sebelum pelajaran ditutup guru meminta siswa melakukan refleksi kesimpulan kegiatan penutup hari ini. Kegiatan refleksi berikut ini:

a. Apa yang paling kalian sukai dari pembelajaran hari ini?

b. Apa yang belum kalian pahami pada pembelajaran hari ini?

2. Guru bersama siswa membuat kesimpulan pembelajaran hari ini.

3. Guru memberikan latihan / evaluasi dalam bentuk google form yang linknya akan dikirim melalui group WA serta menjelaskan batas waktu pengumpulan hasil jawaban evaluasi.

4. Penugasan pada siswa untuk membuat pantun dengan tema menghargai jasa para pahlawan.

5. Guru memberikan pujian dan motivasi kepada siswa yang mampu mengungkapkan pendapatnya dalam memberikan kesimpulan.

6. Guru menyampaikan nilai moral yang terkait dengan pembelajaran hari ini.

Marilah kita menjaga kesehatan tubuh kita dengan cara tidur yang teratur, olah raga, dan minum multivitamin agar tubuh kita tetap sehat dan kuat. Kita harus tidur teratur karena saat kita tidur organ tubuh kita beristirahat, karena jika tubuh kita tidak beristirahat maka organ-organ yang didalam tubuh kita akan terus bekerja.

Ada baiknya juga menyimpulkan dikaitkan dengan indikator karakter nasionalis.

7. Mengajak semua siswa berdo'a untuk mengakhiri kegiatan pembelajaran hari ini 
Tabel 1. Lembar Observasi Guru dalam Pelaksanaan Pengkondisian Karakter Nasionalis pada Materi Pantun dan Syair Serta Peredaran Darah

\begin{tabular}{|c|c|c|c|c|}
\hline No & $\begin{array}{l}\text { Indikator Karakter } \\
\text { Nasionalis }\end{array}$ & $\begin{array}{l}\text { Kegiatan Pembelajaran dalam } \\
\text { Indikator Karakter Nasionalis }\end{array}$ & Skor & Keterangan \\
\hline 1 & $\begin{array}{l}\text { Bangga sebagai bangsa } \\
\text { Indonesia }\end{array}$ & $\begin{array}{l}\text { Menggali pantun bertema bangga } \\
\text { sebagai bangsa Indonesia }\end{array}$ & 4 & $\begin{array}{l}\text { Penjelasana guru } \\
\text { sangat meyakinkan }\end{array}$ \\
\hline 2 & $\begin{array}{l}\text { Cinta tanah air dan } \\
\text { bangsa }\end{array}$ & Mengupas syair bertema cinta tanah air & 1 & $\begin{array}{l}\text { Kurang tampak } \\
\text { kesungguhan }\end{array}$ \\
\hline 3 & $\begin{array}{l}\text { Rela berkorban demi } \\
\text { bangsa }\end{array}$ & $\begin{array}{l}\text { Mendorong siswa membuat pantun } \\
\text { bertema rela berkorban }\end{array}$ & 3 & $\begin{array}{l}\text { Dorongan yang guru } \\
\text { berikan baik }\end{array}$ \\
\hline 4 & $\begin{array}{l}\text { Menerima } \\
\text { kemajemukan }\end{array}$ & $\begin{array}{l}\text { Menganalogikan ragam alat peredaran } \\
\text { darah dan ragam budaya/etnis }\end{array}$ & 3 & $\begin{array}{l}\text { Menganalogikan } \\
\text { pada siswa baik }\end{array}$ \\
\hline 5 & $\begin{array}{l}\text { Bangga pada budaya } \\
\text { beraneka ragam }\end{array}$ & $\begin{array}{l}\text { Mengupas ragam alat peredaran darah } \\
\text { sebagai suatu kebesaran Tuhan, dan } \\
\text { kebanggaan yang sama pada budaya } \\
\text { beraneka ragam }\end{array}$ & 2 & $\begin{array}{l}\text { Cara mengupas } \\
\text { kurang tampak } \\
\text { kesungguhan, lebih } \\
\text { cenderung datar }\end{array}$ \\
\hline 6 & $\begin{array}{l}\text { Menghargai jasa para } \\
\text { pahlawan }\end{array}$ & $\begin{array}{l}\text { Mendorong siswa membuat tugas } \\
\text { rumah tentang pantun bertema } \\
\text { menghargai jasa para pahlawan }\end{array}$ & 3 & $\begin{array}{l}\text { Mendorong siswa } \\
\text { dengan semangat } \\
\text { membuat pantun }\end{array}$ \\
\hline 7 & $\begin{array}{l}\text { Mengutamakan } \\
\text { kepentingan negara dari } \\
\text { pada kepentingan } \\
\text { individu atau kelompok }\end{array}$ & $\begin{array}{l}\text { Menjelaskan kasus bahwa antara ragam } \\
\text { alat peredaran darah, mana yang lebih } \\
\text { penting antara satu dengan yang lain, } \\
\text { selanjutnya menganalogikan dengan } \\
\text { kepentingan negara }\end{array}$ & 0 & $\begin{array}{l}\text { Tak muncul dalam } \\
\text { pelaksanaan } \\
\text { pembelajaran }\end{array}$ \\
\hline
\end{tabular}

Skor Kemunculan: (1) Kegiatan Pembelajaran Muncul Indikator Karakter Nasionalis Sangat Baik maka skor 4; (2) Kegiatan Pembelajaran Muncul Indikator Karakter Nasionalis Baik maka skor 3; (3) Kegiatan Pembelajaran Muncul Indikator Karakter Nasionalis Cukup maka skor 2; (4) Kegiatan Pembelajaran Muncul Indikator Karakter Nasionalis Kurang maka skor 1; (5) Kegiatan Pembelajaran Tidak Muncul Indikator Karakter Nasionalis maka skor 0; (6) Keterangan diisi berupa penjelasan terkait pemberian skor.

Bila memperhatikan tabel penskoran di atas, ternyata total skor diperoleh yaitu 16 dari 7 aspek. Dengan demikian rata-rata skornya yakni 16:7 = 2,29 . Dapat dikatakan bahwa pengkondisian karakter nasionalis dalam pembelajaran materi pantun dan syair serta peredaran darah tergolong sedang. Ini berarti untuk ke depan pada tahapan berikutnya sebaiknya beberapa bagian yang kurang maksimal, perlu diupakan untuk lebih maksimal dalam pelaksanaannya.

Ada dua kegiatan pembelajaran di dalam lembar observasi yang tergolong kurang maksimal, yaitu mengupas syair bertema cinta tanah air dan menjelaskan kasus bahwa antara ragam alat peredaran darah, mana yang lebih penting antara satu dengan yang lain, selanjutnya menganalogikan dengan kepentingan negara. Dua kegiatan pembelajarn tersebut memang diakui sukar untuk maksimal.

Mengupas syair bertema cinta tanah air tergolong sukar, dapat dicermati daari aspek materi ajar syair. Banyak pengajar/guru memandang bahwa syair bagi siswa belum terbiasa. Dalam prakteknya dilapangan, ternyata kesulitan penerapan syair dalam kehidupan sehari-hari banyak tantangan. Sesuai informasi guru bahwa pembuatan syair memiliki tingkat kesulitan yang berbeda dibanding dengan pantun. Dan ternyata pembuatan pantun lebih mudah dibanding dengan membuat syair.

Guru tidak melakukan penjelasan tentang kasus peredaran darah yang dapat dianalogikan pada keperluan negara. 'Informasi dari guru bahwa kebingungan untuk menganalogikan sesuai dengan pada butir ke-7 tersebut. Pertama, bagi guru tidak terbiasa dalam pembelajaran selalu dibawa dalam analogi. Kedua, guru tergolong lupa dengan kegiatan pembelajaran yang memuat butir ke-7.

\section{SIMPULAN DAN SARAN}

\section{Simpulan}

Berdasarkan paparan hasil dan pembahasan permasalahan tersebut dapat dapat disimpulkan sebagai berikut: (1) pengkondisian karakter nasionalis oleh guru tergolong sedang atau biasabiasa saja, perlu pembiasaan pada siswa agar pengkondisian karakter nasionalis dapat berjalan baik atau sangat baik; (2) tidak semua butir indikator karakter nasionalis untuk dapat direalisasikan.

\section{Saran}

Ada beberapa saran untuk kajian berikutnya agar tak mengulang bagian yang kurang maksimal: (1) bagian yang belum maksimal disebabkan belum terbiasa, maka perlu dilakukan sesering mungkin; dan (2) bagian yang tak muncul perlu ada catatan tersendiri agar tidak terlewatkan dalam pembelajaran. 


\section{DAFTAR RUJUKAN}

Badan Penelitian dan Pengembangan, Kemndikbud. (2019). Model Penilaian Karakter. Jakarta: Pusat Penilaian Pendidikan.

Elihami, E., \& Firawati, F. (2017). Transformasi Sosial dalam Nilai-Nilai Pendidikan Islam di
Kabupaten Sidenreng Rappang. Edumaspul: Jurnal Pendidikan, 1(2), 51-60.

Lickona, Thomas. (1991). Educating for Character: How Our School Can Teach Respect and Responsibility. New York, Toronto, London, Sydney, Aucland: Bantam books. 